\title{
In vivo investigations into the carbene gold anticancer drug candidates NHC*-Au-SCN and NHC*-Au-Scyclo
}

\author{
Wolfgang Walther ${ }^{\mathrm{ab}}$, Oyinlola Dada ${ }^{\mathrm{c}}$, Ingo Ott ${ }^{\mathrm{d}}$, Agnieszka Prochnicka ${ }^{\mathrm{d}}$, Britta Büttner ${ }^{\mathrm{e}}$, \\ Xiangming $\mathrm{Zhu}^{\mathrm{c}}$ and Matthias Tacke ${ }^{\mathrm{c}, *}$ \\ ${ }^{a}$ Max Delbrück Center for Molecular Medicine, Robert-Rössle-Str. 10, D-13125; \\ ${ }^{b}$ Experimental and Clinical Research Center, Charité Universitätsmedizin Berlin, \\ Lindenberger Weg 80, D-13125 Berlin, Germany. 'School of Chemistry, University College Dublin, \\ Belfield, Dublin 4, Ireland. Institute of Medicinal and Pharmaceutical Chemistry, \\ Technische Universität Braunschweig, Beethovenstr. 55, D-38106 Braunschweig; \\ ${ }^{\mathrm{e}} \mathrm{EPO}$ GmbH Berlin-Buch, Robert-Rössle-Str. 10, D-13125 Berlin, Germany.
}

\begin{abstract}
The anticancer drug candidate 1,3-dibenzyl-4,5diphenyl-imidazol-2-ylidene gold(I) thiocyanate $\left(\mathrm{NHC}^{*}-\mathrm{Au}-\mathrm{SCN}\right)$ and its cyclohexane thiolate derivative (NHC*-Au-Scyclo) exhibited very good activity against human colon cancer with $\mathrm{GI}_{50}$ values against human HCT116 colon cancer cells of 0.40 and $1.65 \mu \mathrm{M}$, respectively. In addition, inhibition of the mammalian thioredoxin reductase (TrxR) was observed with $\mathrm{IC}_{50}$ values of $0.77 \pm$ $0.34 \mu \mathrm{M}$ for $\mathrm{NHC}^{*}$-Au-SCN and $13 \pm 4 \mu \mathrm{M}$ for $\mathrm{NHC}^{*}$-Au-Scyclo. This encouraged maximum tolerable dose (MTD) experiments in mice, where MTD values of $10 \mathrm{mg} / \mathrm{kg}$ for NHC*-Au-SCN and $30 \mathrm{mg} / \mathrm{kg}$ for $\mathrm{NHC}^{*}$-Au-Scyclo were determined with single injections to groups of 2 mice. In the subsequent tumor xenograft experiment $\mathrm{NHC}^{*}$-Au-SCN and $\mathrm{NHC}^{*}$-Au-Scyclo were applied three times at two doses in groups of 6 HCT116 tumor-bearing NMRI:nu/nu mice. The control group comprising 6 mice was treated with the solvent only. $\mathrm{NHC}^{*}$-Au-SCN at the dose of 5 and $10 \mathrm{mg} / \mathrm{kg}$ and $\mathrm{NHC}^{*}$-Au-Scyclo at the higher dose of 15 and $30 \mathrm{mg} / \mathrm{kg}$ showed tolerability towards the drugs, while no significant body weight loss was seen in both groups. $\mathrm{NHC}^{*}$-AuSCN exerted only weak antitumoral activity
\end{abstract}

\footnotetext{
*Corresponding author: matthias.tacke@ucd.ie
}

reflected by $\mathrm{T} / \mathrm{C}$ values of 0.81 and 0.65 . The tumor volume growth reduction induced by $\mathrm{NHC}^{*}$-Au-Scyclo was better, with optimal T/C values of 0.58 and 0.31 being observed at doses of $15 \mathrm{mg} / \mathrm{kg}$ and $30 \mathrm{mg} / \mathrm{kg}$, respectively. Alterations in dosing and/or application schedules might further improve the antitumoral activity, particularly for $\mathrm{NHC}^{*}$-Au-Scyclo.

KEYWORDS: carbene-gold anticancer drug, NCI 60 cancer cell panel, thioredoxin reductase, HCT116 colon cancer, xenograft mouse model.

\section{INTRODUCTION}

Colorectal cancer is the third most common cancer worldwide, with almost 1.4 million new cases diagnosed every year [1]. If not detected early and removed by surgery, these cancers have a reasonable number of chemotherapeutic treatment options like FOLFOX (leucovorin, 5-FU, and oxaliplatin) or FOLFIRI (leucovorin, 5-FU, and irinotecan). New targeted compounds like Bevacizumab, Ramucirumab, Cetuximab or Panitumumab and others give a certain amount of hope to patients with advanced colorectal cancer, since these compounds can block the vascular endothelial growth factor (VEGF) or epidermal growth factor receptor (EGFR) pathways. Nevertheless, one out of three colorectal cancer 
patients dies in countries with advanced treatment options within five years [2]. These clinical facts suggest that new therapeutic regimens must be explored in the quest to develop an effective therapy for these metastatic or advanced forms of colorectal cancer.

There is significant unexplored space for chemotherapeutic coinage metal-based drugs [3] targeting difficult-to-treat cancers. Already in 2008 a publication by Youngs suggested that carbenesilver acetato complexes derived from 4,5-dichloroimidazole may have the stability and antitumoral activity to become anticancer drug candidates [4]. The idea was further pursued and led to the development of more lipophilic benzyl-substitute dimidazole- and benzimidazole-derived carbenesilver, -gold, and -ruthenium complexes showing activity against the human renal cancer line CAKI1 [5-23]. So far, the most promising derivative 1-methyl-3-( $p$-cyanobenzyl)benzimidazole-2-ylidene silver(I) acetate (SBC1) showed activity against CAKI-1 cells with an $\mathrm{IC}_{50}$ value of $1.2 \mu \mathrm{M}$ [20], which is superior when compared to cisplatin. Due to its lipophilicity and suitable shape, the anticancer drug candidate SBC1 binds well to albumin and interacts with DNA in vitro, but failed to show an antitumoral effect in vivo [24]. However, further synthesis led to 1,3-di(p-methoxybenzyl)-4,5-di ( $p$-isopropylphenyl)-imidazol-2-ylidene copper(I) bromide (WBC4), which shows nanomolar activity with an $\mathrm{IC}_{50}$ value of $0.65 \mu \mathrm{M}$ against CAKI-1 cells [25] and a significant antitumoral effect against renal-cell cancer in vivo [26]. Recently, we published the antitumoral effects of 1,3dibenzyl-4,5-diphenyl-imidazol-2-ylidene gold(I) chloride( $\left.\mathrm{NHC}^{*}-\mathrm{Au}-\mathrm{Cl}\right)$ and its 2',3',4',6'-tetra-Oacetyl-beta-D-glucopyranosyl-1'-thiolate derivative (NHC*-Au-SR) [11]; both compounds showed good activity against the renal cell line CAKI-1 with $\mathrm{GI}_{50}$ values of $1.74 \mu \mathrm{M}$ and $2.00 \mu \mathrm{M}$ in vitro and significant activity in a xenograft CAKI-1 mouse model in vivo $[27,28]$.

The present study investigates the anti-proliferative effect of further two carbene-gold anticancer drug candidates; gold derivatives are known for showing an interesting apoptosis mechanism targeting mitochondria [29] via thioredoxin reductase (TrxR) inhibition [30]. Thus, 1,3-dibenzyl-4,5-diphenylimidazol-2-ylidene gold(I) thiocyanate (NHC*$\mathrm{Au}-\mathrm{SCN}$ ) and its cyclohexane thiolate derivative
(NHC*-Au-Scyclo) exhibited very good activity against human colon cancer with $\mathrm{GI}_{50}$ values against HCT116 cells of 0.40 and $1.65 \mu \mathrm{M}$, respectively [31]. NHC*-Au-SCN and $\mathrm{NHC}^{*}-\mathrm{Au}-$ Scyclo were tested as TrxR inhibitors in vitro as well as for their activity and toxicity in a HCT116 colon cancer xenograft mouse model in vivo. The structures of $\mathrm{NHC}^{*}-\mathrm{Au}-\mathrm{SCN}, \mathrm{NHC}^{*}$-Au-Scyclo, $\mathrm{NHC}^{*}-\mathrm{Au}-\mathrm{Cl}$ and $\mathrm{NHC}^{*}-\mathrm{Au}-\mathrm{SR}$ are shown in Figure 1.

\section{MATERIALS AND METHODS}

\section{Synthesis of NHC*-Au-SCN and NHC*-Au-Scyclo}

$\mathrm{NHC}^{*}$-Au-SCN and $\mathrm{NHC}^{*}$-Au-Scyclo were freshly prepared from the corresponding $\mathrm{NHC}^{*}-\mathrm{Au}-\mathrm{Cl}$ precursor as reported earlier [31].

\section{Inhibition of mammalian thioredoxin reductase}

To determine the inhibition of mammalian TrxR an established microplate reader-based assay was performed. For this purpose, commercially available rat liver TrxR (from Sigma-Aldrich) was used and diluted with distilled water to achieve a concentration of $3.58 \mathrm{U} / \mathrm{mL}$. The compounds, $\mathrm{NHC}^{*}$-Au-SCN and $\mathrm{NHC}^{*}$-Au-Scyclo, were freshly dissolved as stock solutions in dimethylformamide (DMF). $25 \mu \mathrm{L}$ aliquots of the enzyme solution and $25 \mu \mathrm{L}$ of either potassium phosphate buffer $\mathrm{pH} 7.0$ containing the compounds in graded concentrations or $25 \mu \mathrm{L}$ buffer without compounds but DMF (positive control) were added. $50 \mu \mathrm{L}$ of a blank solution (DMF in buffer) was also prepared (final concentrations of DMF: $0.5 \% \mathrm{~V} / \mathrm{V}$ ). The resulting solutions were incubated with moderate shaking for $75 \mathrm{~min}$ at $37^{\circ} \mathrm{C}$ in a 96 -well plate. To each well, $225 \mu \mathrm{L}$ warm reaction mixture $(1 \mathrm{~mL}$ reaction mixture consists of $500 \mu \mathrm{L}$ potassium phosphate buffer $\mathrm{pH} 7.0,80 \mu \mathrm{L}$ ethylenediamine tetraacetate (EDTA) solution (100 mM, pH 7.5), $20 \mu \mathrm{L}$ bovine serum albumin (BSA) solution $(0.2 \%), 100 \mu \mathrm{L}$ of the reduced form of nicotinamide adenine dinucleotide phosphate (NADPH) solution $(20 \mathrm{mM})$ and $300 \mu \mathrm{L}$ distilled water) were added and the reaction started immediately by addition of $25 \mu \mathrm{L}$ of $20 \mathrm{mM}$ ethanolic solution of 5,5'-dithio-bis-[2-nitrobenzoic acid] (DTNB). After proper mixing, the formation of 5-TNB 
<smiles>N#Sc1ccccc1CN1C(c2ccccc2)=C(c2ccccc2)N(Cc2ccccc2)C1[14CH](c1ccccc1)c1ccccc1</smiles>

NHC*-Au-SCN<smiles>Cl[14C]1C(c2ccccc2)N(Cc2ccccc2)C1N1C(c2ccccc2)=C(c2ccccc2)N(Cc2ccccc2)C1[14Cl]</smiles>

$\mathrm{NHC} *-\mathrm{Au}-\mathrm{Cl}$

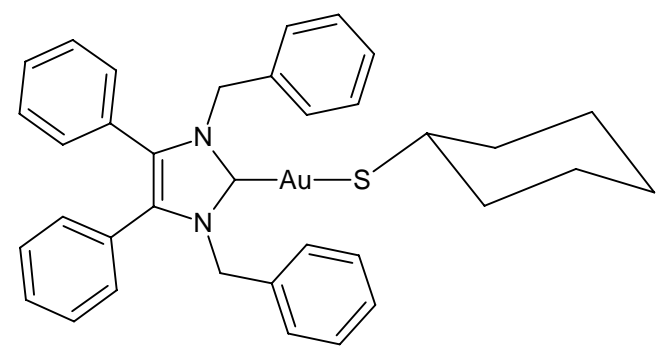

NHC*-Au-Scyclo

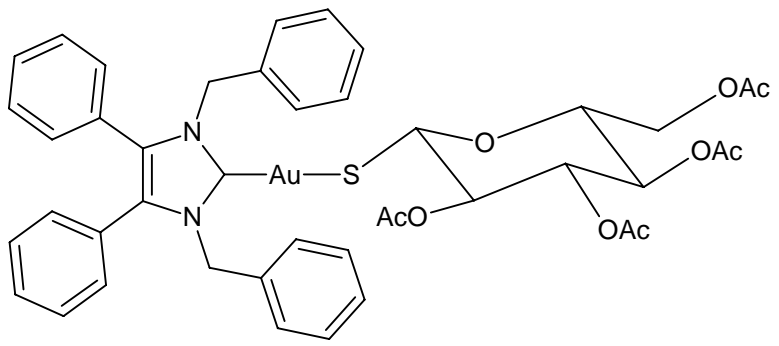

NHC*-Au-SR

Figure 1. Molecular structure of the carbene-gold compounds NHC*-Au-SCN, NHC*-Au-Scyclo, $\mathrm{NHC}^{*}-\mathrm{Au}-\mathrm{Cl}$ and $\mathrm{NHC}^{*}-\mathrm{Au}-\mathrm{SR}$.

was monitored with a microplate reader at $37{ }^{\circ} \mathrm{C}$ at $405 \mathrm{~nm}$ for about $6 \mathrm{~min}(10$ times in $35 \mathrm{~s}$ intervals). The increase in 5-TNB concentration over time followed a linear trend $\left(r^{2} \geq 0.990\right)$, and the enzymatic activities were calculated as the slopes (increase in absorbance per second) thereof. For each tested compound, the noninterference with the assay components was confirmed by a negative control experiment using an enzyme-free test solution. The $\mathrm{IC}_{50}$ values were calculated as the concentration of compound decreasing the enzymatic activity of the untreated control by $50 \%$ and are given as the means and error of three repeated experiments.

\section{HCT116 human colon carcinoma xenograft model}

The in vivo experiments were performed at EPO $\mathrm{GmbH}$ Berlin in a single study. All animals were received from Janvier Labs; housing and animal care was in accordance to all legal and ethical regulations. In the first animal experiment the maximum tolerable dose (MTD) of $\mathrm{NHC}^{*}$-Au$\mathrm{SCN}$ and $\mathrm{NHC}^{*}$-Au-Scyclo was determined in female NMRI:nu/nu mice. Both compounds were dissolved in dimethylsulfoxide (DMSO) (final concentration $10 \%$ ) and further diluted with $5 \%$ Tween 80 in saline. Female NMRI:nu/nu mice ( $\mathrm{n}=2$ mice per group) were administered with $2.5,5,10,20,30$ and $40 \mathrm{mg} / \mathrm{kg}$ of $\mathrm{NHC}^{*}-\mathrm{Au}-$ $\mathrm{SCN}$ or $\mathrm{NHC}^{*}-\mathrm{Au}-\mathrm{Scyclo}$ intraperitoneally (i.p.) in single injections of $0.1 \mathrm{ml}$ in order to determine the approximate MTD. In this experiment maximum body weight loss and side effects were documented.

In the second in vivo experiment $1 \times 10^{7}$ HCT116 cells (expanded in vitro in RPMI medium $+10 \%$ fetal bovine serum) were injected subcutaneously (s.c.) in a volume of $0.1 \mathrm{ml}$ to female NMRI:nu/nu mice ( $\mathrm{n}=6$ mice per group) on day 0 . When tumors were grown to a palpable size of around $0.1 \mathrm{~cm}^{3}$ mice were randomised and treatment was initiated on day 9 . For groups $\mathrm{B}$ and $\mathrm{C}$ the experimental anticancer drug $\mathrm{NHC}^{*}-\mathrm{Au}-\mathrm{SCN}$ and for groups $\mathrm{D}$ and $\mathrm{E} \mathrm{NHC*}$-Au-Scyclo were injected into mice i.p. at doses of 5 or $10 \mathrm{mg} / \mathrm{kg}$ (group $\mathrm{B} / \mathrm{C}$ ) and 15 or $30 \mathrm{mg} / \mathrm{kg}$ (groups $\mathrm{D} / \mathrm{E}$ ) on days 9,13 , and 17 , while the control group (group A) of mice was treated with the solvent 
only. Tumor volumes (TV) were measured with a caliper instrument at indicated time points and calculated using the formula: $\mathrm{TV}=\left(\right.$ width $^{2} \mathrm{x}$ length) $/ 2$. Tumor volumes, relative tumor volumes (relation to the first treatment day) and treated to control $(\mathrm{T} / \mathrm{C})$ values were calculated. Body weight and health conditions of the mice were determined continuously during the experiments to estimate tolerability of the drug. Mice were sacrificed 7 days after their last treatment and necropsy was performed for evaluation of side effects.

The animal experiments were performed according to the German Animal Protection Law and with approval from the responsible local authorities (LaGeSo Berlin, Germany). The in vivo procedures were consistent and in compliance with the United Kingdom Co-ordinating Committee on Cancer Research (UKCCCR) guidelines.

\section{Statistical analysis}

Statistical evaluation of all experiments was performed using the one-way anova test and Bonferroni-correction. The level of statistical significance was defined with a $p$-value of $p \leq 0.05$.

\section{RESULTS AND DISCUSSION}

\section{NHC*-Au-SCN and NHC*-Au-Scyclo effects on the inhibition of mammalian thioredoxin reductase}

The inhibition of mammalian TrxR through NHC*-Au-SCN is significant and reaches an $\mathrm{IC}_{50}$ value of $0.77 \pm 0.34 \mu \mathrm{M}$, while in $\mathrm{NHC}^{*}$-AuScyclo the inhibition effect was weaker and reaches an $\mathrm{IC}_{50}$ value of $13 \pm 4 \mu \mathrm{M}$. This is significantly weaker than the inhibition of TrxR by Auranofin (Triethylphosphino gold(I) 2,3,4,6tetra-O-acetyl-alpha-D-glucopyranosyl-1-thiolate) with an $\mathrm{IC}_{50}$ value of $90 \mathrm{nM}$ [32], but compares well to other NHC-Au(I)-X complexes, which have typical values in the single digit micromolar region [33].

\section{NHC*-Au-SCN and NHC*-Au-Scyclo mediated growth inhibition on HCT116 xenograft tumors}

In the mouse experiment for the determination of MTD female NMRI:nu/nu mice $(\mathrm{n}=2$ mice per group) were treated with single doses of $\mathrm{NHC}^{*}$-Au-SCN or $\mathrm{NHC}^{*}$-Au-Scyclo ranging from $2.5-40 \mathrm{mg} / \mathrm{kg}$. In general, both compounds were tolerated well by the animals. For NHC*$\mathrm{Au}-\mathrm{SCN}$, doses of up to $15 \mathrm{mg} / \mathrm{kg}$ were tolerated without body weight loss, while for $\mathrm{NHC}^{*}$-AuScyclo the dosage could be extended to $40 \mathrm{mg} / \mathrm{kg}$ without generation of side effects for the animals. From these investigations doses of 5 and 10 ( $\mathrm{NHC}^{*}$-Au-SCN) or 15 and 30 (NHC*-Au-Scyclo) $\mathrm{mg} / \mathrm{kg}$ were derived as well-tolerated doses for further therapeutic experiment with an extended treatment period for the tumor-bearing mice.

In the HCT116 s.c. tumor xenograft experiment all tumors grew progressively and the tumors reached a palpable size of around $0.1 \mathrm{~cm}^{3}$ on day 9. Therefore, five groups of 6 mice each were treated at days 9,13 and 17 intraperitoneally with the solvent (group A), NHC*-Au-SCN (groups $\mathrm{B} / \mathrm{C}$ ) or $\mathrm{NHC}^{*}$-Au-Scyclo solution (group $\mathrm{D} / \mathrm{E}$ ). One of the mice in the high dosage group $\mathrm{E}$ died on day 14 , while another from group B died after the treatment period on day 21 . The treated mice from groups B to E showed no significant body weight loss when compared to the mice of the untreated group A. Figure 2A shows the body weight development of all groups during the experiment, while dosing and application schedules of the HCT116 xenograft experiment are shown in Table 1.

As shown in Figure 2B, all treatment groups B-E showed a tumor volume increase after the first treatment on day 9 and reached mean tumor volumes of $0.417 \mathrm{~cm}^{3}$ (group B), $0.333 \mathrm{~cm}^{3}$ (group C), $0.300 \mathrm{~cm}^{3}$ (group D) and $0.163 \mathrm{~cm}^{3}$ (group E) on day 13, while the control cohort (group A) showed continued tumor growth and reached a significantly higher tumor volume of $0.514 \mathrm{~cm}^{3}$. After that, treatments were given on day 13 and the tumors grew to mean tumor volumes of $0.749 \mathrm{~cm}^{3}$ (group B), $0.565 \mathrm{~cm}^{3}$ (group C), $0.449 \mathrm{~cm}^{3}$ (group D) and $0.370 \mathrm{~cm}^{3}$ (group E) on day 16, while the tumors in the control animals (group A) reached a higher tumor volume of $0.702 \mathrm{~cm}^{3}$. After another injection on day 17 the tumors in the treated groups showed further increased volumes of $1.024 \mathrm{~cm}^{3}$ (group B), $0.953 \mathrm{~cm}^{3}$ (group C), $0.741 \mathrm{~cm}^{3}$ (group D) and $0.696 \mathrm{~cm}^{3}$ (group E) on day 20. However, for the 
A (Mean) Body weight [g]



Tumor growth HCT116 s.c. tumors

B



Figure 2. Influence of $\mathrm{NHC}^{*}$-Au-SCN and $\mathrm{NHC}^{*}$-Au-Scyclo treatments on body weight (A) and growth of HCT116 xenotransplant tumors (B) in NMRI nu/nu mice. The animals were treated with $5 \mathrm{mg} / \mathrm{kg}$ and $10 \mathrm{mg} / \mathrm{kg}$ of NHC*-Au$\mathrm{SCN}$ and with $15 \mathrm{mg} / \mathrm{kg}$ and $30 \mathrm{mg} / \mathrm{kg}$ of NHC*-Au-Scyclo at days 9, 13 and 17. The therapeutic effects were determined by measuring the tumor volumes. The standard deviations are given as SEM.

control cohort (group A) a higher tumor volume of $1.145 \mathrm{~cm}^{3}$ was measured. The treatment with $\mathrm{NHC}^{*}$-Au-SCN generated T/C values of 0.81 and 0.65 for groups $\mathrm{B}$ and $\mathrm{C}$, both on day 13 . The
$\mathrm{NHC}^{*}$-Au-Scyclo treatment achieved optimal T/C values of 0.58 for the $15 \mathrm{mg} / \mathrm{kg}$ dose (group D) and 0.31 for the animals that received $30 \mathrm{mg} / \mathrm{kg}$ (group E), both on day 13 . 
Table 1. Overview of results obtained in the HCT116 xenograft experiment. Female NMRI nu/nu mice received subcutaneous tumor cell injections on day 0 . Starting at palpable tumor size the mice were treated with $\mathrm{NHC}^{*}-\mathrm{Au}-\mathrm{SCN}, \mathrm{NHC}^{*}$-Au-Scyclo or the solvent at days 9, 13 and 17. Tumor size in the treated group in relation to the control group (T/C) was measured as a therapeutic marker, while the number of deaths and the body weight change were used as toxicity parameters.

\begin{tabular}{|c|c|c|c|c|c|c|c|}
\hline Group & $\begin{array}{c}\text { Number } \\
\text { of mice }\end{array}$ & Substance & $\begin{array}{c}\text { Treatment } \\
\text { [on day] }\end{array}$ & Route & $\begin{array}{c}\text { Dose } \\
\text { (mg/kg) }\end{array}$ & $\begin{array}{c}\text { Opt. T/C } \\
\text { [on day] }\end{array}$ & $\begin{array}{c}\text { Deaths } \\
\text { [on day] }\end{array}$ \\
\hline A & 6 & Solvent & $9,13,17$ & i.p. & & & $0 / 6$ \\
\hline B & 6 & NHC*-Au-SCN & $9,13,17$ & i.p. & 5 & $0.81[13]$ & $1 / 6[21]$ \\
\hline C & 6 & NHC*-Au-SCN & $9,13,17$ & i.p. & 10 & $0.65[13]$ & $0 / 6$ \\
\hline D & 6 & NHC*-Au-Scyclo & $9,13,17$ & i.p. & 15 & $0.58[13]$ & $0 / 6$ \\
\hline E & 6 & NHC*-Au-Scyclo & $9,13,17$ & i.p. & 30 & $0.31[13]$ & $1 / 6[14]$ \\
\hline
\end{tabular}

\section{CONCLUSION}

The experimental anticancer drug candidates $\mathrm{NHC}^{*}$-Au-SCN and $\mathrm{NHC}^{*}$-Au-Scyclo showed very good cytotoxic activity against the human colon cancer cell line HCT116 exhibiting $\mathrm{GI}_{50}$ values of 0.40 and $1.65 \mu \mathrm{M}$ and significant inhibition of mammalian TrxR reaching $\mathrm{IC}_{50}$ values of $0.77 \pm 0.34 \mu \mathrm{M}$ and $13 \pm 4 \mu \mathrm{M}$, respectively. This encouraged further preclinical development by testing the antitumoral activities in xenografted HCT116 tumors in mice. From the first in vivo experiments using non-tumor bearing mice and single injections, MTD values of $10 \mathrm{mg} / \mathrm{kg}$ and $30 \mathrm{mg} / \mathrm{kg}$ were determined for $\mathrm{NHC}^{*}$-Au-SCN and $\mathrm{NHC}^{*}$-Au-Scyclo. In the therapeutic xenograft experiment using HCT116 tumor-bearing mice these MTD values proved to be (moderately) effective and of tolerable toxicity. When exposed to 3 MTD dosages of 10 or $30 \mathrm{mg} / \mathrm{kg}$ of $\mathrm{NHC}^{*}-\mathrm{Au}-\mathrm{SCN}$ or $\mathrm{NHC}^{*}-\mathrm{Au}-$ Scyclo, respectively, only one mouse in the $\mathrm{NHC}^{*}$-Au-Scyclo cohort died during the treatment on day 14 , while a moderate $\mathrm{T} / \mathrm{C}$ value of 0.65 was reached on day 13 for $\mathrm{NHC}^{*}$-Au-SCN and a good T/C value of 0.31 for $\mathrm{NHC}^{*}$-Au-Scyclo on day 13. Such activity compares well with other gold-based drugs tested in vivo recently [34-36]. This treatment demonstrated that $\mathrm{NHC}^{*}$-AuScyclo has a useable therapeutic index probably in an optimised formulation.

\section{ACKNOWLEDGEMENTS}

The authors gratefully acknowledge University College Dublin (UCD) for funding. The authors are thankful for the excellent technical support of S. Gromova with respect to the xenograft experiments. None of the authors has a commercial interest in developing $\mathrm{NHC}^{*}-\mathrm{Au}-\mathrm{SCN}$ or $\mathrm{NHC}^{*}$ $\mathrm{Au}-\mathrm{Scyclo}$ as drugs.

\section{CONFLICT OF INTEREST STATEMENT}

None of the authors have a financial interest in developing $\mathrm{NHC}^{*}$-Au-SCN and $\mathrm{NHC}^{*}$-Au-Scyclo into anticancer drugs.

\section{REFERENCES}

1. B. W. Stewart and C. P. Wild (Eds.) World Cancer Report 2014, World Health Organization, WHO Press, Geneva, Switzerland.

2. American Cancer Society, Colorectal Cancer Facts \& Figures 2014-2016, American Cancer Society, Atlanta, USA.

3. Tan, S. J., Yan, Y. K., Lee, P. P. F. and Lim, K. H. 2010, Future Med. Chem., 2, 1591.

4. Medvetz, D. A., Hindi, K. M., Panzner, M. J., Ditto, A. J., Yun, Y. H. and Youngs, W. J. 2008, Metal-Based Drugs, Article ID 384010 , 7, doi:10.1155/2008/384010. 
5. Patil, S. A., Patil, S. A., Keri, R. S., Budagumpi, S., Balakrishna, G. and Tacke, M. 2015, Future Med. Chem., 7, 1305.

6. Tacke, M. 2015, J. Organomet. Chem., 782, 17.

7. Tacke, M. 2015, Novel Carbene-Metal Complexes as Anticancer Drugs and Antibiotics - Potential and Limitations, Insights into Coordination, Bioinorganic and Applied Inorganic Chemistry. M. Melník, P. Segl'a and M. Tatarko, Eds., Press of Slovak University of Technology, Bratislava, 12, 188.

8. Browne, N., Hackenberg, F., Streciwilk, W., Tacke, M. and Kavanagh, K. 2014, Biometals, 27, 745 .

9. Hackenberg, F. and Tacke, M. 2014, Dalton Trans., 43, 8144 .

10. Streciwilk, W., Cassidy, J., Hackenberg, F., Müller-Bunz, H., Paradisi, F. and Tacke, M. 2014, J. Organomet. Chem., 749, 88.

11. Hackenberg, F., Müller-Bunz, H., Smith, R., Streciwilk, W., Zhu, X. and Tacke, M. 2013, Organometallics, 32, 5551.

12. Hackenberg, F., Lally, G., Müller-Bunz, H., Paradisi, F., Quaglia, D., Streciwilk, W. and Tacke, M. 2013, Inorg. Chim. Acta, 395, 135.

13. Sharkey, M. A., O'Gara, J. P., Gordon, S. V., Hackenberg, F., Healy, C., Paradisi, F., Patil, S., Schaible, B. and Tacke, M. 2012, Antibiotics, 1, 25.

14. Hackenberg, F., Lally, G., Müller-Bunz, H., Paradisi, F., Quaglia, D., Streciwilk, W. and Tacke, M. 2012, J. Organomet. Chem., 717, 123.

15. Hackenberg, F., Deally, A., Lally, G., Malenke, S., Müller-Bunz, H., Paradisi, F., Patil, S., Quaglia, D. and Tacke, M. 2012, Int. J. Inorg. Chem., Article ID 121540, 13, doi:10.1155/2012/121540

16. Kaps, L., Biersack, B., Müller-Bunz, H., Mahal, K., Münzner, J., Tacke, M., Mueller, T. and Schobert, R. 2012, J. Inorg. Biochem., 106, 52.

17. Patil, S., Deally, A., Hackenberg, F., Kaps, L., Müller-Bunz, H., Schobert, R. and Tacke, M. 2011, Helv. Chim. Acta, 94, 1551.

18. Patil, S. and Tacke, M. 2011, NHC-Silver(I) Acetates as Bioorganometallic Anticancer and Antibacterial Drugs, Insights into Coordination,
Bioinorganic and Applied Inorganic Chemistry. M. Melník, P. Segl'a and M. Tatarko, Eds., Press of Slovak University of Technology, Bratislava, 10, 555.

19. Patil, S., Deally, A., Gleeson, G., Hackenberg, F., Müller-Bunz, H., Paradisi, F. and Tacke, M. 2011, Z. Allg. Anorg. Chem., 637, 386.

20. Patil, S., Deally, A., Gleeson, B., MüllerBunz, H., Paradisi, F. and Tacke, M. 2011, Metallomics, 3, 74.

21. Patil, S., Dietrich, K., Deally, A., Gleeson, B., Müller-Bunz, H., Paradisi, F. and Tacke, M. 2010, Helv. Chim. Acta, 93, 2347.

22. Patil, S., Deally, A., Gleeson, B., MüllerBunz, H., Paradisi, F. and Tacke, M. 2010, Appl. Organomet. Chem., 24, 781.

23. Patil, S., Claffey, J., Deally, A., Gleeson, B., Hogan, M., Menéndez Méndez, L. M., Müller-Bunz, H., Paradisi, F. and Tacke, M. 2010, Eur. J. Inorg. Chem., 1020.

24. Fichtner, I., Behrens, D., Cinatl Jr., J., Michaelis, M., Sanders, L. C., Hilger, R., Kennedy, B. N., Reynolds, A. L., Hackenberg, F., Lally, G., Quinn, S. J., McRae, I. and Tacke, M. 2012, Letters in Drug Design \& Discovery, 9, 815.

25. Streciwilk, W., Hackenberg, F., Müller-Bunz, H. and Tacke, M. 2014, Polyhedron, 80, 3.

26. Walther, W., Fichtner, I., Hackenberg, F., Streciwilk, W. and Tacke, M. 2014, Letters in Drug Design \& Discovery, 11, 825.

27. Walther, W., Dada, O., O'Beirne, C., Ott, I., Sánchez-Sanz, G., Schmidt, C., Werner, C., Zhu, X. and Tacke, M. 2017, Letters in Drug Design \& Discovery, 14, 125.

28. Tacke, M. 2015, Coinage Metal NHC Complexes as Novel Antibiotics and Anticancer Drugs, Insights into Coordination, Bioinorganic and Applied Inorganic Chemistry. M. Melník, P. Segla and M. Tatarko, Eds., Press of Slovak University of Technology, Bratislava, 13, 123.

29. Tonissen, K. F. and Di Trapani, G. 2009, Mol. Nutr. Food Res., 53, 87.

30. Barnard, P. J. and Berners-Price, S. J. 2007, Coord. Chem. Rev., 251, 1889.

31. Dada, O., Curran, D., O'Beirne, C., MüllerBunz, H., Zhu, X. and Tacke, M. 2017, J. Organometal. Chem., 840, 30. 
32. Rubbiani, R., Kitanovic, I., Alborzinia, H., Can, S., Kitanovic, A., Onambele, L. A., Stefanopoulou, M., Geldmacher, Y., Sheldrick, W. S., Wolber, G., Prokop, A., Wölfl, S. and Ott, I. 2010, J. Med. Chem., 53, 8608.

33. Rubbiani, R., Schuh, E., Meyer, A., Lemke, J., Wimberg, J., Metzler-Nolte, N., Meyer, F., Mohr, F. and Ott, I. 2013, Med. Chem. Commun., 4, 942.

34. Fernández-Gallardo, J., Elie, B. T., Sulzmaier, F. J., Sanaú, M., Ramos, J. W. and Contel, M. 2014, Organometallics, 33, 6669.

35. García-Moreno, E., Tomás, A., AtriánBlasco, E., Gascón, S., Romanos, E., Rodriguez-Yoldi, M. J., Cerrada, E. and Laguna, M. 2016, Dalton Trans., 45, 2462.

36. Muenzner, J. K., Biersack, B., Albrecht, A., Rehm, T., Lacher, U., Milius, W., Casini, A., Zhang, J. -J., Ott, I., Brabec, V., Stuchlikova, O., Andronache, I. C., Kaps, L., Schuppan, D. and Schobert, R. 2016, Chem. Eur. J., 22, 18953. 